\title{
Effective Selection Criteria for Genotype of Winged Bean based on Comparative Study of Stability and Sustainability
}

\author{
H.L. Raiger ${ }^{1^{*}}$ and N.K. Jajoriya ${ }^{2}$ \\ ${ }^{1}$ AICRN on Potential Crops, NBPGR, Pusa Campus, New Delhi-12, India \\ ${ }^{2}$ Baba Farid institutions technology, HNB Garhwal Central University Dehradun, India \\ National Bureau of Plant Genetic Resources, Pusa Campus, New Delhi, 110 012, India \\ *Corresponding author
}

\begin{tabular}{|c|}
\hline Keywords \\
\hline $\begin{array}{l}\text { Winged bean, } \\
\text { Sustainability } \\
\text { index, Yield, } \\
\text { Stability parameter }\end{array}$ \\
\hline Article Info \\
\hline $\begin{array}{l}\text { Accepted: } \\
12 \text { February } 2019 \\
\text { Available Online: } \\
10 \text { March } 2019\end{array}$ \\
\hline
\end{tabular}

Keywords

Winged bean, Sustainability index, Yield, Stability parameter

\section{A B S T R A C T}

Comparative studies on stability parameters and proposed Genotypic selection index for selecting stable genotypes in wingedbean (Psophocarpus tetragonolobus) was carried out according to Eberthart and Russel model with sustainability index model. In stability analysis was carried out on 10 genotypes for seed yield, pod yield, days to flowering, maturity and plant height on 3 year multi location data viz., 2005, 2006 and 2007. The based on linear component ( $b i)$, and non-linear response $\left(S^{2} d_{i}\right)$ and high mean performance $(\bar{x})$, EC038955 and Mysore Local for seed yield; EC178331 for pod yield in favourable environment. While based on sustainability index and best performance, the genotypes EC038955 and NBRI-Sel were found to be stable. The similarly, for 100 seed weight (g) deviation from regression was non-significant for genotypes EC178313. Whereas on the basis of sustainability index, mean performance selection index were found stable. For maturity the genotypes recorded very high sustainability index, which indicated that this character is least influenced by the environmental factor. it could be concluded that the genotypes'EC038955', NBRI-Sel were the most suitable variety for all the environments for seed yield and pod yield. Thus, there is ample scope of improvement in yields by use of stable and high yielding genotypes.

\section{Introduction}

The Winged bean (Psophocarpus tetragonolobus), also known as the Goa bean (kacang botol in Malaysia), is a tropical legume plant native to Papua New Guinea. It grows abundantly in hot, humid equatorial countries, from the Philippines and Indonesia to India, Burma and Sri Lanka. It does well in humid tropics with high rainfall. This bean has been called the "one species supermarket" because practically all of the plant is edible. The beans are used as a vegetable, but the other parts (leaves, flowers, and tuberous roots) are also edible. The tender pods, which are the most widely eaten part of the plant, can be harvested within two to three months of planting. The flowers are often used to color rice and pastries. The flavor of the beans has a similarity to asparagus. The young leaves can 
be picked and prepared as a leaf vegetable, similar to spinach. The roots can be used as a root vegetable, similar to the potato, and have a nutty flavor; they are also much more rich in protein than potatoes. The dried seeds can be useful as a flour and also to make a coffee-like drink. Each of these parts of the winged bean provide a source of vitamin $A$ and other vitamins. Seed yields greater than $20 \mathrm{q} / \mathrm{ha}$ and green pod yield of over $350 \mathrm{q} /$ ha have been reported from Papua New Guinea and Malaysia, respectively. In India, yields reported from experimental plots are of the order of $7-15 \mathrm{q} / \mathrm{ha}$ seed, $40-95 \mathrm{q} /$ ha green pods and $48-60 \mathrm{q} / \mathrm{ha}$ tubers. Thus, there is ample scope of improvement in yields by use of stable and high yielding genotypes. It is possible that, with a little genetic improvement through selective breeding, the winged bean could raise the standard of living for millions of people in poor, tropical countries.

\section{Materials and Methods}

The experiment, comprising nine genotypes and one check variety 'AKWB-1' was laid out in randomized bock design with three replications at different locations of All India Coordinated Research Network Project on Underutilized Crops during kharif season. These locations were Ambikapur (Chhattisgarh), Bhubaneswar (Orissa), Rahuri (Maharashtra) in 2005; Rahuri (Maharashtra), Ranchi (Jharkhand) in 2006; Rahuri (Maharashtra) in 2007 (Table 1).

Each genotype seed yield /plot was recorded to estimate its yield potential. The data were analysed for stability parameters, viz mean $(\overline{\mathrm{x}})$, regression coefficient $\left(\mathrm{b}_{\mathrm{i}}\right)$ and deviation from regression $\left(\mathrm{S}^{2} \mathrm{~d}_{\mathrm{i}}\right)$ as per model proposed by Eberhart and Russell (1966). The sustainability indices were worked out as per the following formula used by earlier workers (Gangwar et al., 2004).
$S I_{(i)} \cdot=\frac{Y-\sigma n}{Y_{M}} \times 100$

Where $\mathrm{Y}=$ average performance of the genotype, $\sigma \mathrm{n}=$ standard deviation and $\mathrm{Y}_{\mathrm{M}}=$ best performance of the genotype at any location in any year.

The values of sustainability index were divided into five groups viz. very low (< $20 \%)$, low (21-40\%), moderate (41-60\%), high $(61-80 \%)$ and very high $(>80 \%)$.

Modified the sustainable index and proposed a new Genotypic selection index based variety performance.

$S_{i}=\frac{S I_{(i)}-\overline{S I}_{(\mathbb{i})}}{S I_{(\mathbb{1})}}$

Eberhart and Russell (1966) used the stability parameters (i) genotypic mean $\left(g_{i}\right)$ expressed as selection index $\left(S_{i}\right)$, (ii) regression value (b) (predictable linear response) and deviation from linearity $\left(S_{d}^{2}\right)$, (unpredictable non-linear response) for identifying genotypes for all environments. According to this model an ideal stable genotype is one which conforms to the following stability parameters: (i) selection index is more than zero, represented by high genotypic mean $\left(S_{i}>0\right.$ i.e.gi $\left.>x\right)$ (ii) regression coefficient is equal to unity $(b=1)$ and (iii) deviation from regression is equal to zero $\left(S_{d}^{2}=0\right)$. Such a genotype would be suitable for general adaptation over all environments.

\section{Results and Discussion}

A stable genotype has a low genotype $(\mathrm{G}) \mathrm{x}$ Environment (E) interaction for agronomically important characters. Assessment of the G X E interaction is necessary to identify phenotypically stable genotype. Regression analysis of the $\mathrm{G} \mathrm{X} \mathrm{E}$ interaction is used to characterized genotypic responses to environments. Eberhart and Russell (1966) 
extended this approach and included deviation from the regression as an additional parameter, an approach widely used by breeders to detect high yielding stable genotypes. Present investigation, pooled analysis of variance indicated (Table 2) that environment and $\mathrm{G} X \mathrm{E}$ interaction were significant for all characters. The $\mathrm{G} X \mathrm{E}$ interaction effect was further partitioned into linear (Predictable) and non-linear (unpredictable) components through analysis of variance for stability. The $\mathrm{E}+\mathrm{G} \mathrm{X} \mathrm{E}$ interaction was significant for all characters also. The differential effects of environment on genotypes were significant for all characters as indicated by environment (linear) mean square. The linear component $\mathrm{G}$ $\mathrm{X} E$ interaction was significant for all traits indicating prediction about performance of most genotypes appeared feasible for these characters. The significant mean squares due to pool deviation observed in all traits indicated that genotype deferred with respect to their stability, representing the unpredictable component of $\mathrm{G} \quad \mathrm{X} \quad \mathrm{E}$ interaction. The analysis of variance (Table 2) showed significant and highly significant differences in means sum of square for genotypes and environments respectively for seed yield indicating the presence of substantial variation among the genotypes and environments. The genotypes also interacted significantly with environments indicating that genotypes behaved differently under different environments for seed yield.

The genotype NBRI-Sel. was not stable for seed yield even though it had stable performance on pod yield and 100 seed weight (g). It also unstable across the environment. Days to $50 \%$ flowering and days to $80 \%$ maturity was stable performance in genotype EC038955.

The detail of genotype sowing stability for different traits determined in Table 7. The genotype EC038955 was stable for seed yield, days to maturity and days to $50 \%$ flowering.

Five genotypes viz 'Dwarf Mutant', 'EC142665', 'EC178313', 'EC178331' and 'IC026945' had more than $9.00 \mathrm{q} / \mathrm{ha}$ seed yield (Table 4). Among them, all genotypes had significant deviation from regression $\left(S^{2} d i\right)$ values. Thus, their performance was non-predictable across the environments. But, the other five genotypes less than $9.00 \mathrm{q} / \mathrm{ha}$ only two genotypes among them namely 'EC038955' and NBRI-Sel had nonsignificant deviation from regression values and thus, their performance was predictable across the environments. Both the genotypes had regression coefficient (bi) values significantly higher than 1 and thus were more suited to better environments. These genotypes had a highest suitability index (60.26) and (60.08) respectively. Therefore, these two genotypes 'EC038955' and 'NBRISel.' could be selected for improving the yield potential in winged bean depending up the environments sought for.

Data on pod yield genotype 'EC178331' had significant regression coefficient $(b i=1.24)$ and non-significant deviation of regression, therefore, it was considered for a suitable genotype for favourable environments, while based on sustainability index 'EC708313' $(57.22 \%)$ and 'IC026945' (59.93\%) was consider stable genotype (Table 5). For 100 seed weight all the genotypes are nonsignificant regression and only one genotype (EC178339) had a non-significant deviation from regression $\left(b i=1.25, S d_{i}^{2}=-0.35\right)$. Days to flowering and maturity are the two important characters that can be used as a measure of earliness. Two parameters of stability and non-significant regression and deviation from regression indicated that the genotype 'AKWB-1' was stable for early flowering. 
Table.1 Sources and availability of Winged bean genotypes

\begin{tabular}{|l|l|l|}
\hline \multicolumn{1}{|c|}{ Genotype } & \multicolumn{1}{c|}{ Source } & \multicolumn{1}{c|}{ Status } \\
\hline Dwarft Mutant & Karnataka & Breeding line \\
\hline EC038955 & NBPGR, Akola & Exotic collection \\
\hline EC142665 & NBPGR, Akola & Exotic collection \\
\hline EC178271 & NBPGR, Akola & Exotic collection \\
\hline EC178313 & NBPGR, Akola & Exotic collection \\
\hline EC178331 & NBPGR, Akola & Exotic collection \\
\hline IC026945 & NBPGR, Akola & Exotic collection \\
\hline Mysore Local & Karnataka & Release variety \\
\hline NBRI-Sel & NBRI, Lucknow & Release variety \\
\hline AKWB-1 (C) & NBPGR, Akola & Release variety \\
\hline
\end{tabular}

Table. 2 Analysis of variance for stability in seed yield and related attributed of winged bean genotypes during 2005-07

\begin{tabular}{|l|c|c|c|c|c|c|}
\hline Source of variation & d.f. & \multicolumn{6}{|c|}{ Sum of Mean square } \\
\cline { 2 - 7 } & & $\begin{array}{c}\text { Seed yield } \\
(\mathbf{q} / \mathbf{h a})\end{array}$ & $\begin{array}{c}\text { 100 seed } \\
\text { weight } \mathbf{( g )}\end{array}$ & $\begin{array}{c}\text { Days to } \\
\mathbf{5 0 \%} \\
\text { flowering }\end{array}$ & $\begin{array}{c}\text { Days to } \\
\mathbf{8 0 \%} \\
\text { maturity }\end{array}$ & $\begin{array}{c}\text { Pod yield } \\
(\mathbf{q} / \mathbf{h a})\end{array}$ \\
\hline Genotypes (G) & 9 & $3.44 * *$ & $10.94 * *$ & $34.63 * *$ & 35.08 & $74.24 * *$ \\
\hline Environments (E) & 5 & $34.66 * *$ & $19.78 * *$ & $429.81^{*} *$ & $685.65 *$ & $668.57 * *$ \\
\hline G x E & 45 & $4.97 * *$ & $4.47 *$ & $12.28 * *$ & $24.68 * *$ & $50.49 * *$ \\
\hline Env. (linear) & 1 & $346.61 * *$ & $197.79 * *$ & $4298.08 * *$ & $6856.41 * *$ & $6685.76 * *$ \\
\hline GxE (linear) & 9 & $7.29 * *$ & $3.58 *$ & $28.23 * *$ & 14.45 & $33.28 *$ \\
\hline Pooled deviation & 40 & $3.95 * *$ & $4.22 *$ & $7.46 * *$ & 24.51 & $49.31 * *$ \\
\hline Pooled Error & $\mathbf{1 0 8}$ & $\mathbf{0 . 2 6}$ & $\mathbf{0 . 6 4}$ & $\mathbf{1 . 3 2}$ & $\mathbf{1 8 . 9 2}$ & $\mathbf{6 . 0 1}$ \\
\hline
\end{tabular}

**, * Significant at $\mathrm{P}=0.01$ and $\mathrm{P}=0.05$, respectively.

Table.3 Value of environmental indices for different traits

\begin{tabular}{|c|l|c|c|c|c|c|c|}
\hline \multirow{2}{*}{ S. No. } & \multicolumn{1}{|c|}{ Traits } & \multicolumn{3}{|c|}{ Kharif-2005 } & \multicolumn{2}{c|}{ Kharif-2006 } & Kharif-2007 \\
\cline { 3 - 8 } & & Ambikapur & Bhubaneswar & Rahuri & Rahuri & Ranchi & Rahuri \\
\hline $\mathbf{1}$ & Seed yield (q/ha) & 1.37 & 4.32 & -2.82 & 0.17 & -2.39 & -0.65 \\
\hline $\mathbf{2}$ & Test weight (g) & 0.71 & -0.61 & -0.82 & -1.27 & 3.70 & -1.71 \\
\hline $\mathbf{3}$ & Days to 50\% flowering & 14.32 & 4.80 & -9.17 & -7.17 & 4.20 & -6.97 \\
\hline $\mathbf{4}$ & Days to 80\% Maturity & 6.78 & 3.73 & -8.77 & -10.07 & 18.53 & -10.20 \\
\hline $\mathbf{5}$ & Pod yield (q/ha) & -13.81 & 1.19 & -9.16 & 11.92 & -5.13 & 14.98 \\
\hline
\end{tabular}


Table.4 Mean and estimate of stability parameters, yield attributes characters of winged bean during 2005-2007

\begin{tabular}{|c|c|c|c|c|c|c|c|c|c|c|c|c|c|c|c|}
\hline \multirow[t]{2}{*}{ Genotypes } & \multicolumn{3}{|c|}{ Seed yield (q/ha) } & \multicolumn{3}{|c|}{100 seed weight (g) } & \multicolumn{3}{|c|}{ Days to $50 \%$ flowering } & \multicolumn{3}{|c|}{ Days to $80 \%$ maturity } & \multicolumn{3}{|c|}{ Pod yield (q/ha) } \\
\hline & Mean & $b i$ & $S d i^{2}$ & Mean & $b i$ & $S d i^{2}$ & Mean & $b i$ & $S d i^{2}$ & Mean & $b i$ & $S d i^{2}$ & Mean & $b i$ & $S d i^{2}$ \\
\hline Dwarft Mutant & & & & & & & & & & & 0.86 & & & 1.13 & $94 * *$ \\
\hline 200 & $8.75 * *$ & & 0.18 & & 1.04 & & & 0.90 & -0.90 & 163.36 & 1.01 & & & 1.25 & 12.76 \\
\hline$E C 142665$ & $9.34 * *$ & $67 * *$ & $15.15 * *$ & $31.49 * *$ & 1.04 & & & 0.90 & $9.77 * *$ & $162.61 * *$ & 0.96 & & $44.54 * *$ & 0.81 & $106.78 * *$ \\
\hline $\mathrm{EC} 178271$ & $7.68 * *$ & $0.95^{* *}$ & 0.56 & $28.89 * *$ & 1.00 & $4.85 * *$ & $69.31 * *$ & $1.56 * *$ & $9.08 * *$ & $166.08 * *$ & $1.21 * *$ & -15.83 & 38.91 & 1.22 & $14.47 * *$ \\
\hline EC178313 & $10.00 * *$ & $1.58 * *$ & 0.94 & $30.02 * *$ & 0.76 & 1.13 & & 0.81 & & $165.56 * *$ & $1.15^{* *}$ & -8.24 & $47.98 * *$ & 0.95 & $62.84 * *$ \\
\hline EC178331 & $9.11 * *$ & $1.02 * *$ & 5.09 & $30.01 * *$ & $1.25^{* *}$ & $-0.35 * *$ & $63.47 * *$ & 0.99 & $8.09 * *$ & $162.22 * *$ & 0.85 & 0.05 & $44.26 * *$ & $1.24 * *$ & -4.40 \\
\hline IC026945 & $9.99 * *$ & 1.61 & 1.11 & $29.32 * *$ & 1.63 & $5.99 * *$ & $62.70 * *$ & 0.77 & $15.42 * *$ & $160.50 * *$ & 0.86 & -3.04 & $46.12 * *$ & 0.60 & $67.24 * *$ \\
\hline Mysore & $8.63 * *$ & 0.78 & $2.96 * *$ & $30.95 * *$ & 1.63 & $2.62 * *$ & $66.63 * *$ & $1.33 * *$ & $7.67 * *$ & $160.89 * *$ & 0.96 & $27.31 * *$ & $38.70 * *$ & 1.04 & 16.27 \\
\hline NRBI-Sel & $8.50 * *$ & 0.68 & -0.06 & $27.80 * *$ & 0.47 & 1.25 & $61.75 * *$ & 0.86 & $2.56 * *$ & $160.83 * *$ & 1.23 & $17.53 * *$ & $39.47 * *$ & 0.74 & $37.20 * *$ \\
\hline AKWB-1(C) & $8.59 * *$ & 0.65 & $5.73 * *$ & $29.93 * *$ & 0.37 & $6.29 * *$ & $63.11 * *$ & 0.98 & -0.64 & $166.50 * *$ & 0.92 & $32.28 * *$ & $38.80 * *$ & 1.03 & $29.92 * *$ \\
\hline
\end{tabular}

**, * Significant at $\mathrm{P}=0.01$ and $\mathrm{P}=0.05$, respectively. 
Table.5 Sustainability index of winged bean during 2005-2007

\begin{tabular}{|l|c|c|c|c|c|}
\hline \multicolumn{1}{|c|}{ Genotypes } & $\begin{array}{c}\text { Seed yield } \\
(\mathbf{q} / \mathbf{h a})\end{array}$ & $\begin{array}{c}\mathbf{1 0 0} \text { seed } \\
\text { weight }(\mathbf{g})\end{array}$ & $\begin{array}{c}\text { Days to 50\% } \\
\text { flowering }\end{array}$ & $\begin{array}{c}\text { Days to 80\% } \\
\text { maturity }\end{array}$ & $\begin{array}{c}\text { Pod yield } \\
(\mathbf{q} / \mathbf{h a})\end{array}$ \\
\hline Dwarft Mutant & $54.96(27)$ & $83.52(5)$ & $72.60(4)$ & $84.95(3)$ & $40.41(17)$ \\
\hline EC038955 & $60.26(39)$ & $76.65(-4)$ & $72.87(4)$ & $84.09(2)$ & $43.36(-11)$ \\
\hline EC142665 & $18.04(-58)$ & $82.56(4)$ & $74.59(6)$ & $85.71(3)$ & $48.58(0)$ \\
\hline EC178271 & $43.58(1)$ & $76.02(-4)$ & $57.15(-18)$ & $80.73(-3)$ & $43.49(-10)$ \\
\hline EC178313 & $32.24(-26)$ & $83.63(5)$ & $77.16(10)$ & $81.04(-2)$ & $57.22(18)$ \\
\hline EC178331 & $37.55(-13)$ & $80.02(1)$ & $68.60(-2)$ & $86.58(5)$ & $47.79(-1)$ \\
\hline IC026945 & $33.65(-22)$ & $70.20(-12)$ & $73.40(5)$ & $83.55(1)$ & $59.93(24)$ \\
\hline Mysore Local & $47.32(9)$ & $73.46(-8)$ & $60.81(-13)$ & $79.50(-4)$ & $44.17(-9)$ \\
\hline NRBI-Sel & $60.08(39)$ & $89.61(-13)$ & $72.85(4)$ & $79.79(-4)$ & $54.74(13)$ \\
\hline AKWB-1(C) & $45.44(5)$ & $78.85(1)$ & $71.02(1)$ & $82.48(0)$ & $45.31(-7)$ \\
\hline
\end{tabular}

$*$ Values in parenthesis indicate selection index (Si).

Table.6 Score chart for stability parameters of genotypes for five characters

\begin{tabular}{|c|c|c|c|c|c|c|}
\hline Genotypes & $\begin{array}{c}\text { Seed yield } \\
(\mathrm{q} / \mathrm{ha})\end{array}$ & $\begin{array}{c}100 \text { seed } \\
\text { weight }(\mathrm{g})\end{array}$ & $\begin{array}{l}\text { Days to } 50 \% \\
\text { flowering }\end{array}$ & $\begin{array}{l}\text { Days to } 80 \% \\
\text { maturity }\end{array}$ & $\begin{array}{c}\text { Pod yield } \\
\text { (q/ha) }\end{array}$ & $\begin{array}{l}\text { Combined } \\
\text { score }\end{array}$ \\
\hline Dwarft Mutant & $\mathrm{m}, \mathrm{r}$ & $\mathrm{m}, \mathrm{r}$ & $\mathrm{m}, \mathrm{r}$ & $\mathbf{m , r}, \mathbf{d}$ & $\mathrm{r}$ & 1 \\
\hline EC038955 & $\mathrm{m}, \mathrm{d}$ & $\mathrm{r}$ & $\mathbf{m}, \mathbf{r}, \mathbf{d}$ & $\mathbf{m}, \mathbf{r}, \mathbf{d}$ & $\mathrm{r}, \mathrm{d}$ & 2 \\
\hline EC142665 & $\mathbf{m}, \mathbf{r}, \mathbf{d}$ & $\mathrm{m}, \mathrm{r}$ & $\mathrm{m}, \mathrm{r}$ & $\mathrm{m}, \mathrm{r}$ & $\mathrm{m}, \mathrm{r}$ & 1 \\
\hline EC178271 & $\mathrm{r}$ & $\mathrm{r}$ & & $\mathrm{d}$ & $\mathrm{r}$ & $\mathbf{0}$ \\
\hline EC178313 & $\mathrm{m}, \mathrm{d}$ & $\mathbf{m}, \mathbf{r}, \mathbf{d}$ & $\mathrm{m}, \mathrm{r}$ & $\mathrm{r}, \mathrm{d}$ & $\mathrm{m}, \mathrm{r}$ & 1 \\
\hline EC178331 & $\mathrm{r}$ & $\mathrm{d}$ & $r$ & $\mathbf{m}, \mathbf{r}, \mathbf{d}$ & $\mathrm{d}$ & $\mathbf{1}$ \\
\hline IC026945 & d & $\mathrm{m}, \mathrm{r}$ & $\mathrm{m}, \mathrm{r}$ & $\mathrm{r}, \mathrm{d}$ & $\mathrm{m}, \mathrm{r}$ & $\mathbf{0}$ \\
\hline Mysore Local & $\mathrm{m}, \mathrm{r}$ & $\mathrm{r}$ & & $\mathrm{r}$ & $\mathrm{r}$ & $\mathbf{0}$ \\
\hline NRBI-Sel & $\mathrm{m}, \mathrm{d}$ & $\mathbf{m}, \mathbf{r}, \mathbf{d}$ & $\mathrm{m}, \mathrm{r}$ & $\mathrm{r}, \mathrm{d}$ & $\mathbf{m}, \mathbf{r}, \mathbf{d}$ & 2 \\
\hline AKWB-1(C) & $\mathrm{m}, \mathrm{r}$ & r & $\mathbf{m}, \mathbf{r}, \mathbf{d}$ & $\mathrm{m}, \mathrm{r}$ & r & $\mathbf{1}$ \\
\hline Combined score & 1 & 2 & 2 & 3 & 1 & \\
\hline
\end{tabular}

Table.7 Genotype sowing stability and high sustainability for traits

\begin{tabular}{|c|l|l|}
\hline S.No. & \multicolumn{1}{|c|}{ Traits } & \multicolumn{1}{c|}{ Genotypes } \\
\hline $\mathbf{1}$ & Seed yield (q/ha) & EC038955 \\
\hline $\mathbf{2}$ & Test weight $(\mathrm{g})$ & EC178313, NRBI-Sel \\
\hline $\mathbf{3}$ & Days to 50\% flowering & EC038955, AKWB-1(C) \\
\hline $\mathbf{4}$ & Days to 80\% Maturity & Dwarft Mutant, EC038955, EC178331 \\
\hline $\mathbf{5}$ & Pod yield (q/ha) & NBRI-Sel. \\
\hline
\end{tabular}


While for the maturity nine genotypes out of ten had non-significant deviation from regression, out of them two genotypes had the significant regression, therefore, seven genotypes was considered for stable for across the environment. Environment indices computed for all characters indicated that Ambikapur and Bhubaneswar environment favoured expression of all the characters in a desirable direction, except pod yield ( $\mathrm{q} / \mathrm{ha}$ ). The test weight was favourable that all environmental conditions (Table 3). A score chart was prepared for all the genotypes and characters. A score chart was prepared for all genotypes and characters. The scores: ' $\mathrm{m}$ ' for significantly higher (desirable) mean, i.e., $\mathrm{Pi}$ is more than zero; ' $r$ ' for ' $b$ ' value not significantly deviating from unity (i.e. $b=1$ ) and 'd' for $\left(S_{d}^{2}\right)$ value not significantly deviating from zero, $S_{d=0}^{2}$, were used. A combined score chart was computed for all genotypes for all characters (Table 6). The combined score chart indicated that EC038955, NBRI-Sel were stable genotype. The only other genotypes which are acceptable for the three parameters for seed yield (q/ha) was IC038955. EC178313 was also identified as the best genotypes for environment best on its mean performance. EC178313, NBRI-Sel was not stable for seed yield even though it had stable performance on test weight. It also unstable across the environment for days to maturity and days to flowering.

On the basis of above findings it could be concluded that the genotypes'EC038955', NBRI-Sel were the most suitable variety for all the environments for seed yield and pod yield.

\section{References}

Eberhart S A and Russell W A. 1966. Stability parameters for comparing varieties. Crop Science 6: 36-40.

Gangwar B, Katyal V and Anand K V. 2004. Stability and efficiency of cropping systems in Chhattisgarh and Madhya Pradesh. Indian Journal of Agricultural Sciences, 74: 521-528.

Maggs-Kolling G L and Christiansen, J L. 2003. Variability in Namibian landraces of watermelon (Citrullus lanatus), Euphytica, 132(3): 251-258.

\section{How to cite this article:}

Raiger, H.L. and Jajoriya, N.K. 2019. Effective Selection Criteria for Genotype of Winged Bean based on Comparative Study of Stability and Sustainability. Int.J.Curr.Microbiol.App.Sci. 8(03): 1371-1377. doi: https://doi.org/10.20546/ijcmas.2019.803.161 